\title{
Extensive Stage Lung Small Cell
}

\section{Carcinoma}

National Cancer Institute

\section{Source}

National Cancer Institute. Extensive Stage Lung Small Cell Carcinoma. NCI Thesaurus.

Code C9049.

Small cell lung carcinoma which has spread beyond one hemi-thorax and the regional lymph nodes. 